\title{
Environmental Risk Assessment of Heavy Metal Pollution in Armenian River Ecosystems: Case Study of Lake Sevan and Debed River Catchment Basins
}

\author{
Gor A. Gevorgyan ${ }^{1,2}$, Armine S. Mamyan ${ }^{1}$, Lusine R. Hambaryan"1, \\ Surik Kh. Khudaverdyan ${ }^{2}$, Ashok Vaseashta ${ }^{3,4 *}$ \\ ${ }^{1}$ Institute of Hydroecology and Ichthyology of the Scientific Center of Zoology and Hydro-ecology of NAS RA, \\ Yerevan, Armenia \\ ${ }^{2}$ Faculty of Radio Engineering and Communication Systems of the National Polytechnic University of Armenia, \\ Yerevan, Armenia \\ ${ }^{3}$ International Clean Water Institute, Manassas, VA, USA \\ ${ }^{4}$ Ghitu Institute of Electronic Engineering and Nanotechnologies, Academy of Sciences of Moldova, \\ Chisinau, Moldova
}

Received: 19 March 2016

Accepted: 15 June 2016

\begin{abstract}
Investigating the mechanisms behind the impact of heavy metal pollution on aquatic ecosystems is urgently required. Due to increasing growth in the mining sector, pollution has become a serious threat to water resources and aquatic biodiversity and is causing unfavorable environmental changes and human health hazards. The aim of the present study was to investigate and assess the environmental risks of heavy metal pollution of river ecosystems in the Lake Sevan and Debed River catchment basins in Armenia, and a thorough study of their qualitative and quantitative parameters. Water samples were taken from the risky river sites of the Sevan and Debed basins in May and August 2013 and 2014. Investigations showed that due to mining and metallurgical industrial activities and the insufficient management of industrial waste and wastewater, the river ecosystems in these territories were exposed to heavy metal pollution, the degree of which in some sites of the Sotq, Masrik (Lake Sevan catchment basin), Debed, Alaverdi, Akhtala, and Chochkan (Debed River catchment basin) rivers may have posed health risks to aquatic life as well as to humans (at least in the case of river water used for drinking purposes). The results of a phytoplankton community study revealed that a decrease in the species diversity of planktonic algae in the investigated rivers was mainly conditioned by the impact of heavy metal pollution induced by mining and metallurgical industrial activities in the Lake Sevan and Debed River catchment basins.
\end{abstract}

Keywords: Lake Sevan catchment basin, Debed River catchment basin, heavy metal pollution, environmental risks, phytoplankton diversity

*e-mail: prof.vaseashta@ieee.org 


\section{Introduction}

Human civilization is a physical sphere of human activity on the earth and is typically associated with pollution, which causes the environment to become dangerous to live in [1]. Rapid urbanization and industrialization have caused the degradation of air, water, and soil quality in most parts of the world [2]. Modern industrial production results in toxic effects on biota that appears to be one of the main factors of manmade ecological risk [3]. Heavy metals are considered major anthropogenic contaminants in aquatic ecosystems worldwide [4-9]. Surface waters are most exposable to pollution due to their easy accessibility for the disposal of wastewaters [10-13]. More and more attention has been drawn due to the wide occurrence of metal pollution in aquatic systems. Heavy metals entered in water can be bioaccumulated in organisms and magnified in food chain, thus threatening human health [7, 10, 14-18]. Humans may be contaminated by heavy metals associated with aquatic ecosystems by the consumption of contaminated fish and other aquatic food $[7,16]$. This fact is due to the capacity of some aquatic organisms to concentrate heavy metals much more than the concentration present in water [16]. Various harmful effects, including the abnormal development of a fetus, procreation failure, and immunodeficiency have been exhibited due to aquatic metal exposure [17-18]. Heavy metals can contribute to the degradation of aquatic ecosystems by reducing species diversity and abundance, and through the accumulation of metals in living organisms and food chains.

Anthropogenically, heavy metals can be introduced to aquatic environments through a variety of sources, especially through industrial waste/discharge, abandoned mines, and/or intentional discharge [6]. Industrial mining activities occur in almost every part of the world [19]. Mining begins with exploration for and discovery of mineral deposits and continues through ore extraction and processing to the closure and remediation of workedout sites. Environmental impacts occur at all of these stages. Mining and beneficiation processes generate four categories of large-volume waste: mine waste (overburden, barren rocks), tailings, dump heap leach, and mine water. Mines produce large amounts of waste because the ore is only a small fraction of the total volume of the mined material [20]. Water in contact with mine deposits often contains large amounts of pollutants such as heavy metals. This can have a devastating impact on surrounding aquatic environments.

One can find several examples of dead lakes and urgent need of remediation methods in mine-adjacent recipients without having to go far back in history. Horntrasket in Vasterbotten is one example of a lake that has been strongly affected by mining industries. Surrounding mines were closed during the 1990s but the lake has not yet recovered from the damage. Leachate with large amounts of toxic metals have continuously reached Lake Horntrasket during the 2000s, despite remediation efforts [21]. Tailing dams contain liquids (toxic, hazardous, or even radioactive) that are pollutant sources of great risk to humans and the environment. Worldwide, at least 63 major tailing dam failures were reported between 1960 and 2014, causing significant pollution. These tailing dam pollution accidents accounted for $62 \%$ of the total number of major tailing dam failures during the same period. Acutely polluted water from dam breaks caused interruptions in the water supply, human fatalities, massive fish kills, agricultural damage, natural reserve failure, and enormous economic loss [19]. There are many studies on the biological effects of metal pollution of the aquatic environment. Investigations carried out by different authors showed that increased heavy metal concentrations in different types of water bodies caused the loss of diversity of benthic and planktonic communities [22-26].

The Lake Sevan catchment basin (Armenia) is situated in the eastern part of the Republic of Armenia (Gegharkunik Province; Fig. 1). Being habitat for endemic fish species such as Khramicarp-Varicorhinus capoeta sevangi Filippi, Barbel-Barbus goktschaicus Kessler, and TroutSalmo ischchan Kessler, it has been affected by various anthropogenic factors such as domestic, agricultural, and industrial activities, etc. It is also necessary to mention that Lake Sevan is the biggest freshwater supply in the Caucasus [27-28]. Hence, the Lake Sevan catchment basin management has always been an important environmental issue for investigators and decision-makers.

Armenia's Debed River Catchment Area is considered one of the industrial centers in Armenia where mining and metallurgical industries are highly developed [29]. Giving priority to the development of the economic sphere, the possible environmental effects of metallurgical industrial activities have been ignored or little attention has been paid. The insufficient management of discharges induced by mining activities in the Debed catchment area has become a serious threat to aquatic ecosystems. It is worth mentioning that Debed is the biggest river in the transboundary Kura River basin, which emphasizes its importance not only on the national but also the international level.

For conserving aquatic ecosystems and ensuring environmental safety and security, investigation of the heavy metal pollution of the Lake Sevan and Debed River catchment basins is urgently required. The aim of the present study was to investigate and assess the environmental risks of the heavy metal pollution of the river ecosystems in the catchment basins.

\section{Area Under Investigation}

We investigated the Sotq and Masrik rivers in the Lake Sevan watershed basin and the Debed and its tributaries (the Pambak, Alaverdi, Akhtala, and Chochkan rivers in the Debed basin; Figs. 1-3, Table 1).

The Lake Sevan catchment basin is situated in the eastern part of the Republic of Armenia (Gegharkunik Province), in $40^{\circ} 25^{\prime}$ north latitude and $45^{\circ} 12^{\prime}$ east longitude. The catchment area is surrounded by the 
mountain ranges of Gegama from the west and by the ridges of Vardenis from the south, Sevan from the east, and Areguni-Pambak from the northeast. This is a large tectonic depression surrounded by mountains, in the northwest of which the watershed line of the basin lowers to lake level. From here starts the only river - the Hrazdan - which flows out of the lake. The surface area of the catchment basin is $4,891 \mathrm{~km}^{2}$. It belongs to the basin of the transboundary Araks river [28]. The 30 rivers and streams flow into Lake Sevan. The Masrik is one of the main rivers flowing into the lake. The lengths of the Masrik and its tributary, the Sotq, are $45 \mathrm{~km}$ and $21 \mathrm{~km}$, respectively [30].

The catchment basin has a continental mountainsteppe climate. The highest average monthly temperature is recorded in August, ranging from 8.8 to $17.6^{\circ} \mathrm{C}$, and the lowest is in January, ranging from -4.6 to $6.4^{\circ} \mathrm{C}$ [31]. Physico-geographical and climatic conditions determine the unique hydrology of the lake catchment basin. Basin hydrology is expressed by the hydrography, flow characteristics, water regime, alimentation, spring flood, maximum and low flows, suspended sediment flow, thermal and ice regimes of rivers, and the water balance of the catchment basin. The flow of the Sevan basin is formed by three sources: underground water, snow, and rain. Due to the large variety of the climatic, geological, and hydrological conditions of the catchment basin, some rivers in the catchment basin have snow alimentation while the others have underground alimentation. Freshets occur in spring [30]. The river waters in the lake catchment basin are mainly used for irrigation and energetic purposes.

The Debed catchment area is situated in Lori Province in northern Armenia and lies between $41^{\circ} 15^{\prime}$ and $40^{\circ} 41^{\prime}$ north latitude and $43^{\circ} 56^{\prime}$ and $44^{\circ} 57^{\prime}$ east longitude. The catchment area is surrounded by the mountain ranges of Virahayoc from the north, Pambak from the south and the southeast, Javakhq from the west, and Gugarac from the east. The surface area of the catchment basin in the territory of Armenia is $3,790 \mathrm{~km}^{2}$ and includes the territory of Lori Province. It belongs to the basin of the transboundary Kura River. The total length of the Debed and its tributary, the Pambak, is $178 \mathrm{~km}, 152 \mathrm{~km}$ of which are located within Armenia. Due to the geographical position, hypsometric fluctuations, atmospheric circulation, and complicated mountain relief of the Debed basin, a comparatively mild and humid climate is found in the area. The highest average monthly temperature is recorded in August, ranging from 32 to $38^{\circ} \mathrm{C}$, and the lowest in January, ranging from -36 to $-22^{\circ} \mathrm{C}$. Due to the geological and hydrogeological structure, relief characteristics, and heavy precipitation of the Debed catchment area, it is characterized by a dense hydrographic network. In the catchment area, the Pambak and Dzoraget are lowland rivers, the Debed is a mountain and lowland river, and others (small rivers) are mainly mountain rivers. The sources of river alimentation in the area include snow, rain, and groundwater. The rivers are characterized by unstable flow regime and large fluctuations in water levels. The large freshets of the rivers occurs in spring and at the beginning of summer (AprilJune), small freshets occur in fall, especially October. The river waters in the catchment area are used for domestic, industrial, energy, and irrigation purposes [32].

Water monitoring and sampling in the risky river sites were implemented in May and August 2013 (Debed) and May and August 2014 (Sevan).

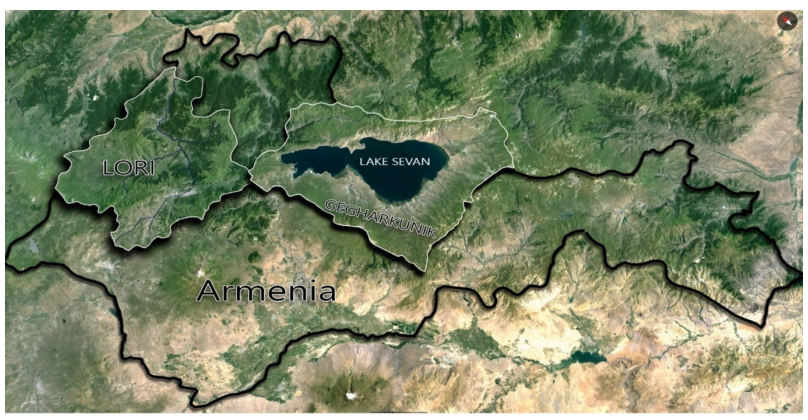

Fig. 1. Map of Armenia showing watershed basins under investigation.

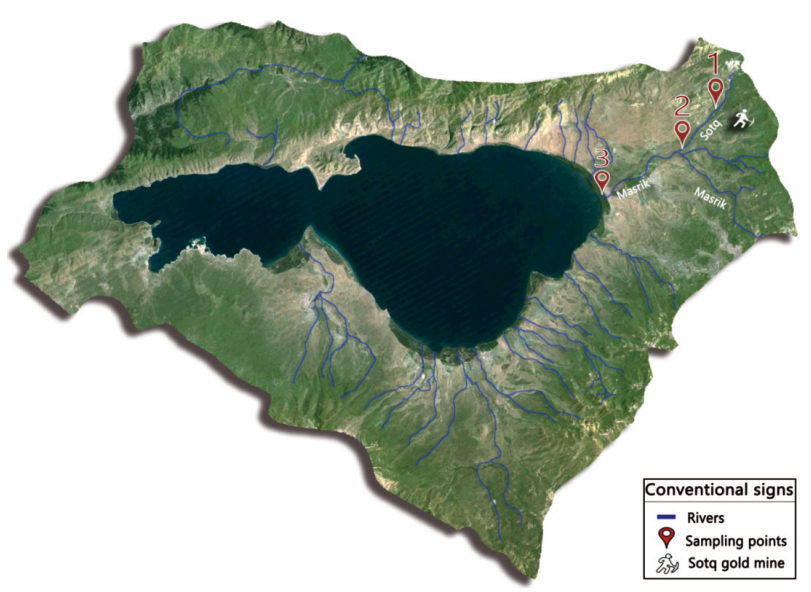

Fig. 2. Map of the monitoring and sampling sites in the Lake Sevan catchment basin.

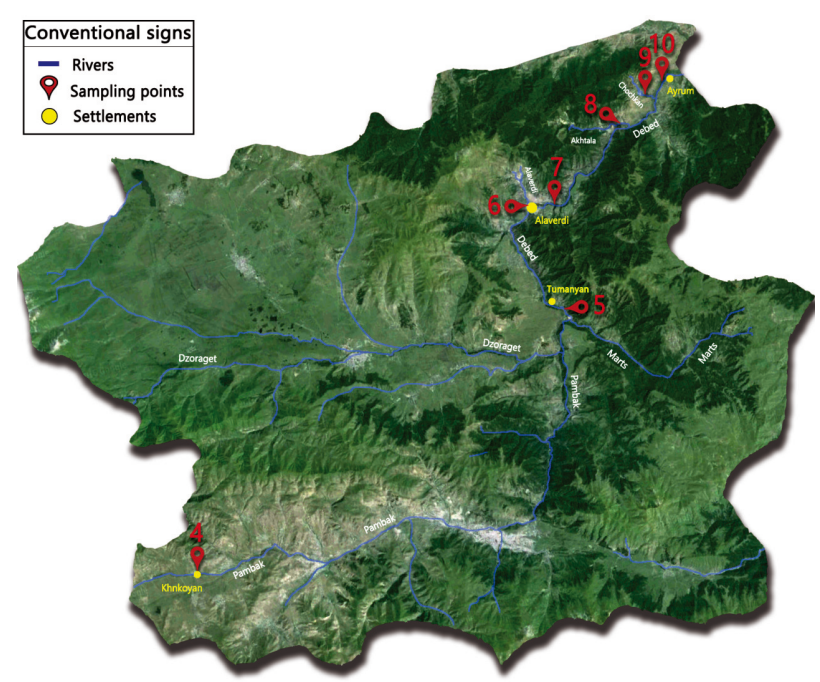

Fig. 3. Map of the monitoring and sampling sites in the Debed river catchment basin. 
Table 1. Coordinates of the rivers investigated sites in the Lake Sevan and Debed river catchment basins under investigation.

\begin{tabular}{|c|c|c|c|}
\hline $\begin{array}{l}\text { Sampling site } \\
\text { number }\end{array}$ & $\mathrm{N} /$ Lat & E/Long & River site location \\
\hline \multicolumn{4}{|c|}{ Lake Sevan catchment basin (Gegharkunik Province) } \\
\hline 1 & $40^{\circ} 14 ’ 14.6 ”$ & $45^{\circ} 57^{\prime} 21.4 ”$ & Sotq river site located about $0.6 \mathrm{~km}$ upstream from the Sotq gold mine \\
\hline 2 & $40^{\circ} 12^{\prime} 17.5^{\prime \prime}$ & $45^{\circ} 48^{\prime} 29.9 ”$ & Sotq river site located near the river mouth \\
\hline 3 & $40^{\circ} 13^{\prime} 09.6 ”$ & $45^{\circ} 39^{\prime} 03.1^{\prime \prime}$ & Masrik river site located near the river mouth \\
\hline \multicolumn{4}{|c|}{ Debed river catchment basin (Lori Province) } \\
\hline 4 & $40^{\circ} 50^{\prime} 27.1 ”$ & $44^{\circ} 01^{\prime} 17.4^{\prime \prime}$ & Pambak river site located in Khnkoyan village \\
\hline 5 & $40^{\circ} 59 ’ 20.3 ”$ & $44^{\circ} 39>12.9 »$ & $\begin{array}{l}\text { Debed river site located about } 4.5 \mathrm{~km} \text { downstream from the point of the confluence } \\
\text { of the Pambak and Dzoraget rivers }\end{array}$ \\
\hline 6 & $41^{\circ} 05^{\prime} 58.0 ”$ & 44³9’16.9” & Alaverdi river site located near the river mouth \\
\hline 7 & $41^{\circ} 06^{\prime} 41.77^{\prime \prime}$ & $44^{\circ} 42^{\prime} 43.26^{\prime \prime}$ & Debed river site located about $4.5 \mathrm{~km}$ downstream from Alaverdi town \\
\hline 8 & $41^{\circ} 08^{\prime} 54.5^{\prime \prime}$ & $44^{\circ} 46^{\prime} 14.9^{\prime \prime}$ & Akhtala river site located near the river mouth \\
\hline 9 & $41^{\circ} 10^{\prime} 27.0^{\prime \prime}$ & $44^{\circ} 49^{\prime} 19.6 ”$ & Chochkan river site located in the downstream from the Chochkan tailing dump \\
\hline 10 & $41^{\circ} 11^{\prime} 16.6^{\prime \prime}$ & $44^{\circ} 53^{\prime} 32.0^{\prime \prime}$ & Debed river site located near Ayrum town \\
\hline
\end{tabular}

\section{Sample Collection}

Water samples for heavy metal, alkalinity, and acidity analyses were taken with cleaned polythene bottles (1 liter) pre-washed with $20 \%$ nitric acid $\left(\mathrm{HNO}_{3}\right)$ and doubledistilled water. Two $\mathrm{ml}$ of concentrated $\mathrm{HNO}_{3}$ were added to the heavy metal samples in order to preserve metals and also to avoid precipitation.

For phytoplankton analysis, a 1-liter water sample taken from each site was preserved with $40 \%$ formaldehyde solution $(0.4 \%$ final concentration) and stored in a dark place. Further study was carried out under laboratory conditions [33].

Temperature and $\mathrm{pH}$ measurements were conducted in field conditions. Water temperature $\left(\mathrm{T}_{\mathrm{w}}\right)$ and air temperature $\left(T_{a}\right)$ were determined using a digital thermometer (ST9265), and water $\mathrm{pH}$ using a multiparameter analyzer (HI98129).

Sample Preparation and Analyses

for Phytoplankton, Heavy Metals, Alkalinity, and Acidity

In the laboratory, the water samples for heavy metal analysis were filtered with Whatman paper No. 41 and refrigerated at $4^{\circ} \mathrm{C}$ until analyses. The water samples in many cases before measurement were evaporated to increase the density of heavy metals in the water, which made it possible to increase the sensitivity of heavy metal measurements. Due to the limited measurement range of a heavy metal analyzer (photometer), the water samples in some cases were diluted to decrease the density of heavy metals in the water. The fixed phytoplankton samples were settled in a dark space for 10-12 days, and then the volume of the experimental samples was decreased from $1,000 \mathrm{ml}$ to $100 \mathrm{ml}$ by a siphon (No. 76). Repeating the same process for the second time, the volume of the experimental samples was reduced to $10 \mathrm{ml}$ [33]. The water samples were analyzed for heavy metals ( $\mathrm{V}, \mathrm{Fe}, \mathrm{Ni}, \mathrm{Cu}, \mathrm{As}, \mathrm{Mo}, \mathrm{Pb}$, Cd, Zn) using a multi-parameter photometer (HI83200) and an atomic absorption spectrophotometer (PG990). The qualitative and quantitative analyses of phytoplankton were executed by a microscope in the Nageotte chamber $(\mathrm{V}=0.1 \mathrm{ml})$. The taxonomic identification of planktonic algae was done by the keys/determinants of freshwater systems [34-36]. Water alkalinity and acidity were determined by the titrimetric method [37]. $50 \mathrm{ml}$ of the sample was added to two clean conical flasks of $250 \mathrm{ml}$. Two drops of phenolphthalein indicator were added to the one sample for alkalinity determination, and two drops of methyl red indicator to the other sample for acidity determination. Then the solutions were titrated with $0.01 \mathrm{M} \mathrm{NaOH}$ solution to a pink end-point. Water alkalinity and acidity were calculated by the following equation:

$$
\text { Alkalinity/Acidity }=\frac{\mathrm{V} \times \mathrm{M} \times 100000}{50}
$$

...where $\mathrm{V}$ is volume of $\mathrm{NaOH}$ used and $\mathrm{M}$ is molarity of $\mathrm{NaOH}$ used.

\section{Environmental Risk Assessment}

Individual heavy metal pollution degree for river ecosystem health was assessed by the following equation [38]:

$$
\mathrm{PI}=\mathrm{C}_{\mathrm{i}} / \mathrm{S}_{\mathrm{i}}
$$


...where PI is the pollution index of each metal, $\mathrm{C}_{\mathrm{i}}$ is the determined concentration of heavy metal $i$, and $S_{i}$ is the maximum permissible concentration of heavy metal $i$ for river ecosystem health [39].

The PI of each metal is classified into four pollution categories: non-pollution $(\mathrm{PI}<1)$, potential pollution $(1 \leq \mathrm{PI}<2)$, slight pollution $(2 \leq \mathrm{PI}<3)$, and heavy pollution $(3 \leq \mathrm{PI})$.

Integrated heavy metal pollution degree for river ecosystem health was evaluated by Nemerow and Sumitomo's water pollution index (NSWPI) [38, 40]:

$$
\text { NSWPI }=\sqrt{\frac{\mathrm{PI}_{\mathrm{avg}}^{2}+\mathrm{PI}_{\mathrm{max}}^{2}}{2}}
$$

...where $\mathrm{PI}_{\text {avg }}$ is the average value of the single pollution indices of all heavy metals and $\mathrm{PI}_{\max }$ is the maximum value of the single pollution indices of all heavy metals.

The average value of the single pollution indices was calculated by the following equation:

$$
\mathrm{PI}_{\mathrm{avg}}=\frac{1}{\mathrm{~m}} \sum_{\mathrm{i}=1}^{\mathrm{n}} \mathrm{PI}_{\mathrm{i}}
$$

...where $\mathrm{PI}_{\mathrm{i}}$ is the single pollution index value of heavy metal $\mathrm{i}$, and $\mathrm{m}$ is the number of heavy metal species.

NSWPI is classified into the following pollution categories: non-pollution (NSWPI $\leq 0.7$ ), warning line of pollution $(0.7<\mathrm{NSWPI} \leq 1)$, slight pollution $(1<\mathrm{NSWPI} \leq 2)$, moderate pollution $(2<\mathrm{NSWPI} \leq 3)$, and heavy pollution (NSWPI>3).

Health risks associated with heavy metals in surface water were examined based on the U.S. Environmental Protection Agency (EPA) risk assessment methodology [41]. The exposure doses were calculated using equations (5) and (6) adopted from the EPA (https://rais.ornl.gov/ documents/HHEMA.pdf):

$$
\mathrm{ED}_{\mathrm{i}}=\frac{\mathrm{C} \times \mathrm{IR} \times \mathrm{ED} \times \mathrm{EF}}{\mathrm{BW} \times \mathrm{AT}}
$$

\begin{tabular}{|c|c|c|c|c|c|c|}
\hline \multirow{3}{*}{ Parameters } & \multicolumn{6}{|c|}{ Sampling site number } \\
\hline & \multicolumn{2}{|c|}{1} & \multicolumn{2}{|c|}{2} & \multicolumn{2}{|c|}{3} \\
\hline & May & Aug & May & Aug & May & Aug \\
\hline V & 2.10 & 3.47 & 4.73 & 10.12 & 10.88 & 14.49 \\
\hline $\mathrm{BL}$ & \multicolumn{4}{|c|}{1.80} & \multicolumn{2}{|c|}{1.20} \\
\hline $\mathrm{Fe}$ & 220.00 & 146.00 & 334.00 & 223.00 & 314.00 & 225.00 \\
\hline $\mathrm{BL}$ & \multicolumn{4}{|c|}{120.00} & \multicolumn{2}{|c|}{110.00} \\
\hline $\mathrm{Ni}$ & 26.17 & 37.46 & 9.07 & 9.27 & 3.20 & 3.69 \\
\hline $\mathrm{BL}$ & \multicolumn{4}{|c|}{38.00} & \multicolumn{2}{|c|}{0.96} \\
\hline $\mathrm{Cu}$ & 1.25 & 1.53 & 1.88 & 2.43 & 2.16 & 2.57 \\
\hline $\mathrm{BL}$ & \multicolumn{4}{|c|}{1.10} & \multicolumn{2}{|c|}{1.50} \\
\hline As & 4.91 & 7.81 & 7.22 & 12.17 & 13.16 & 8.74 \\
\hline $\mathrm{BL}$ & \multicolumn{4}{|c|}{1.60} & \multicolumn{2}{|c|}{0.40} \\
\hline Mo & 0.41 & 0.63 & 0.39 & 0.94 & 1.24 & 1.82 \\
\hline $\mathrm{BL}$ & \multicolumn{4}{|c|}{0.50} & \multicolumn{2}{|c|}{1.10} \\
\hline $\mathrm{Pb}$ & 0.26 & 0.14 & 0.37 & 0.23 & 1.49 & 0.87 \\
\hline $\mathrm{BL}$ & \multicolumn{4}{|c|}{0.18} & \multicolumn{2}{|c|}{0.17} \\
\hline $\mathrm{T}_{\mathrm{w}}\left({ }^{\circ} \mathrm{C}\right)$ & 12.2 & 22.1 & 15.5 & 23.4 & 13.3 & 17.5 \\
\hline $\mathrm{T}_{\mathrm{a}}\left({ }^{\circ} \mathrm{C}\right)$ & 21.5 & 30.8 & 24.9 & 31.6 & 23.2 & 27.1 \\
\hline $\mathrm{pH}$ & 7.86 & 8.50 & 7.83 & 9.10 & 7.60 & 8.84 \\
\hline Alkalinity (mg/l) & 33.6 & 31.4 & 37.3 & 38.8 & 35.8 & 39.2 \\
\hline Acidity (mg/l) & 3.7 & 4.2 & 4.6 & 4.3 & 4.8 & 5.4 \\
\hline
\end{tabular}

Table 2. Heavy metal concentrations (mcg/l) and some physicochemical parameters in the Sotq and Masrik rivers of the Lake Sevan catchment basin.

BL" - background level 
Table 3. Heavy metal concentrations (mcg/l) and some physicochemical parameters in the Pambak, Debed, Alaverdi, Akhtala and Chochkan rivers of the Debed river catchment basin.

\begin{tabular}{|c|c|c|c|c|c|c|c|c|c|c|c|c|c|c|}
\hline \multirow{3}{*}{ Parameters } & \multicolumn{14}{|c|}{ Sampling site number } \\
\hline & \multicolumn{2}{|c|}{4} & \multicolumn{2}{|c|}{5} & \multicolumn{2}{|c|}{6} & \multicolumn{2}{|c|}{7} & \multicolumn{2}{|l|}{8} & \multicolumn{2}{|c|}{9} & \multicolumn{2}{|c|}{10} \\
\hline & May & Aug & May & Aug & May & Aug & May & Aug & May & Aug & May & Aug & May & Aug \\
\hline $\mathrm{Ni}$ & 1.71 & 1.69 & 2.12 & 1.88 & 4.79 & 4.15 & 2.42 & 3.55 & 9.82 & 8.48 & 11.93 & 6.55 & 7.87 & 2.48 \\
\hline $\mathrm{BL}$ & \multicolumn{14}{|c|}{1.10} \\
\hline $\mathrm{Cu}$ & 4.00 & 5.00 & 10.00 & 8.00 & 238.00 & 315.00 & 79.00 & 86.00 & 788.00 & 381.00 & 379.00 & 84.00 & 53.00 & 21.00 \\
\hline $\mathrm{BL}$ & \multicolumn{14}{|c|}{3.00} \\
\hline As & 0.70 & 1.12 & 1.11 & 1.57 & 2.99 & 3.28 & 3.89 & 2.99 & 7.47 & 2.47 & 4.16 & 2.38 & 3.16 & 2.73 \\
\hline $\mathrm{BL}$ & \multicolumn{14}{|c|}{0.42} \\
\hline $\mathrm{Pb}$ & 0.70 & 1.32 & 1.27 & 0.95 & 5.64 & 4.62 & 2.22 & 2.99 & 12.42 & 15.98 & 5.81 & 4.20 & 10.17 & 2.32 \\
\hline $\mathrm{BL}$ & \multicolumn{14}{|c|}{0.66} \\
\hline $\mathrm{Cd}$ & 0.01 & 0.01 & 0.05 & 0.05 & 2.86 & 3.67 & 3.34 & 3.15 & 17.47 & 32.75 & 4.94 & 3.75 & 1.60 & 0.94 \\
\hline BL & \multicolumn{14}{|c|}{0.24} \\
\hline $\mathrm{Zn}$ & 5.30 & 8.90 & 11.90 & 10.30 & 318.30 & 543.90 & 209.10 & 240.90 & 3200.00730 & 5200.00 & 687.60 & 421.40 & 148.40 & 45.30 \\
\hline BL & \multicolumn{14}{|c|}{4.30} \\
\hline $\mathrm{T}_{\mathrm{w}}\left({ }^{\circ} \mathrm{C}\right)$ & 19.8 & 21.2 & 11.6 & 18.5 & 16.0 & 17.8 & 12.0 & 19.7 & 15.4 & 25.2 & 18.3 & 24.5 & 12.0 & 23.2 \\
\hline $\mathrm{T}_{\mathrm{a}}\left({ }^{\circ} \mathrm{C}\right)$ & 29.8 & 30.5 & 21.0 & 27.7 & 25.7 & 26.2 & 21.8 & 28.0 & 24.7 & 34.3 & 27.8 & 32.5 & 21.6 & 31.5 \\
\hline $\mathrm{pH}$ & 8.09 & 8.17 & 7.90 & 8.47 & 8.03 & 8.25 & 7.55 & 8.24 & 7.71 & 7.89 & 7.38 & 8.14 & 8.07 & 8.64 \\
\hline $\begin{array}{c}\text { Alkalinity } \\
(\mathrm{mg} / \mathrm{l})\end{array}$ & 39.4 & 41.2 & 32.1 & 37.7 & 32.8 & 31.1 & 30.4 & 36.4 & 41.7 & 37.3 & 38.5 & 34.2 & 41.3 & 44.7 \\
\hline $\begin{array}{l}\text { Acidity } \\
(\mathrm{mg} / \mathrm{l})\end{array}$ & 3.4 & 4.1 & 4.6 & 4.2 & 3.9 & 4.4 & 4.8 & 4.1 & 5.4 & 4.9 & 3.7 & 4.2 & 4.5 & 5.3 \\
\hline
\end{tabular}

"BL" - background level

$$
\mathrm{ED}_{\mathrm{d}}=\frac{\mathrm{C} \times \mathrm{K}_{\mathrm{p}} \times \mathrm{ET} \times \mathrm{ED} \times \mathrm{EF} \times \mathrm{SA} \times \mathrm{CF}}{\mathrm{BW} \times \mathrm{AT}}
$$

...where $\mathrm{ED}_{\mathrm{i}}$ is exposure dose through the ingestion of water $(\mathrm{mg} / \mathrm{kg} / \mathrm{day}), \mathrm{ED}_{\mathrm{d}}$ is exposure dose through the dermal absorption of water $(\mathrm{mg} / \mathrm{kg} /$ day $), \mathrm{C}$ is measured heavy metal concentration $(\mathrm{mg} / \mathrm{l})$ in water, IR is water ingestion rate for receptor (1/day), ET is exposure time (hours/day), ED is exposure duration (years), EF is exposure frequency (days/year), $\mathrm{K}_{\mathrm{p}}$ is dermal permeability coefficient (cm/hour), SA is skin surface area available for exposure $\left(\mathrm{cm}^{2}\right), \mathrm{CF}$ is volumetric conversion factor $\left(1 / \mathrm{cm}^{3}\right)$, $\mathrm{BW}$ is average body weight $(\mathrm{kg})$, and AT is averaging time for non-carcinogens (days).

The hazard quotient was calculated by equation (7) to estimate non-carcinogenic risks:

$$
H Q_{i / d}=\frac{E D_{i / d}}{R f D_{i / d}}
$$

...where $\mathrm{HQ}_{\mathrm{i} / \mathrm{d}}$ is hazard quotient via ingestion/dermal contact with water (unit less), $\mathrm{ED}_{\mathrm{i} / \mathrm{d}}$ is exposure dose through the ingestion/dermal absorption of water, and
$\mathrm{RfD}_{\mathrm{i} / \mathrm{d}}$ is ingestion/dermal reference dose for water (mg/ $\mathrm{kg} / \mathrm{d})$ [42-44].

According to equation (8), the sum of individual $\mathrm{HQ}_{\mathrm{i} / \mathrm{d}}$ of each metal, expressed as the hazard index $\left(\mathrm{HI}_{\mathrm{i} / \mathrm{d}}\right)$ via ingestion/dermal contact with water, was used to assess overall non-carcinogenic effects posed by all metals:

$$
\mathrm{HI}_{\mathrm{i} / \mathrm{d}}=\sum_{\mathrm{i}=0}^{\mathrm{n}} \mathrm{HQ}_{\mathrm{i} / \mathrm{d}}
$$

Simpson diversity index (SDI) was performed for assessing the diversity of phytoplankton in the conditions of heavy metal pollution [45]:

$$
\mathrm{SDI}=1-\left(\frac{\sum \mathrm{n}(\mathrm{n}-1)}{\mathrm{N}(\mathrm{N}-1)}\right)
$$

...where $\mathrm{n}$ is the total number of organisms of a particular species, $\mathrm{N}$ is the total number of organisms of all species, and SDI represents a range between 0 and 1 ( 0 being no diversity and 1 representing infinite diversity). Statistical analysis was performed using Statistica 8 software. 
Table 4. Heavy metal pollution degree (for river ecosystem health) and SDI values in the Sotq and Masrik rivers of the Lake Sevan basin.

\begin{tabular}{|c|c|c|c|c|c|c|c|c|c|c|c|c|c|c|c|c|c|}
\hline $\begin{array}{c}\text { Sampling } \\
\text { site } \\
\text { number }\end{array}$ & $\mathrm{PI}_{\mathrm{v}}$ & PD & $\mathrm{PI}_{\mathrm{Fe}}$ & PD & $\mathrm{PI}_{\mathrm{Ni}}$ & PD & $\mathrm{PI}_{\mathrm{Cu}}$ & PD & $\mathrm{PI}_{\mathrm{As}}$ & PD & $\mathrm{PI}_{\mathrm{Mo}}$ & PD & $\mathrm{PI}_{\mathrm{Pb}}$ & PD & NSWPI & PD & SDI \\
\hline \multicolumn{18}{|c|}{ May } \\
\hline 1 & 0.3 & \multirow[b]{2}{*}{ NP } & 0.4 & \multirow{3}{*}{ NP } & 0.5 & \multirow{3}{*}{ NP } & $<0.1$ & \multirow{3}{*}{ NP } & 0.1 & \multirow{3}{*}{ NP } & 0.2 & \multirow{3}{*}{ NP } & $<0.1$ & \multirow{3}{*}{ NP } & 0.4 & \multirow{2}{*}{ NP } & 0.87 \\
\hline 2 & 0.7 & & 0.7 & & 0.2 & & $<0.1$ & & 0.1 & & 0.2 & & $<0.1$ & & 0.5 & & 0.80 \\
\hline 3 & 2.3 & SP & 0.6 & & 0.1 & & $<0.1$ & & 0.3 & & 0.3 & & 0.1 & & 1.6 & SP & 0.67 \\
\hline \multicolumn{18}{|c|}{ August } \\
\hline 1 & 0.5 & NP & 0.3 & \multirow{3}{*}{ NP } & 0.7 & \multirow{3}{*}{ NP } & $<0.1$ & \multirow{3}{*}{ NP } & 0.2 & \multirow{3}{*}{ NP } & 0.3 & \multirow{3}{*}{ NP } & $<0.1$ & \multirow{3}{*}{ NP } & 0.6 & NP & 0.85 \\
\hline 2 & 1.4 & PP & 0.4 & & 0.2 & & $<0.1$ & & 0.2 & & 0.5 & & $<0.1$ & & $>1.0$ & SP & 0.70 \\
\hline 3 & 3.0 & HP & 0.4 & & 0.1 & & 0.1 & & 0.2 & & 0.4 & & $<0.1$ & & 2.2 & MP & 0.61 \\
\hline
\end{tabular}

"PD" - pollution degree; "NP" - non-pollution; "PP" - potential pollution; "SP" - slight pollution; "MP" - moderate pollution, "HP" - heavy pollution

\section{Results and Discussion}

The concentrations of heavy metals in some rivers of the Sevan and Debed basins are presented in Tables 2 and 3. The results of the study showed that heavy metal concentrations in the waters of the investigated rivers were conditioned by both lithogenic and anthropogenic sources, as the concentrations of different heavy metals in all the investigated observation sites of the rivers exceeded the background level, which indicated the existence of anthropogenic pressure on the river ecosystems. Heavy metal content in sampling site Nos. 1 and 4 was mostly conditioned by natural factors. Nevertheless, its content in the other investigated observation sites was mainly formed

Table 5. Heavy metal pollution degree (for river ecosystem health) and SDI values in the Pambak, Debed, Alaverdi, Akhtala and Chochkan rivers of the Debed river catchment basin.

\begin{tabular}{|c|c|c|c|c|c|c|c|c|c|c|c|c|c|c|c|}
\hline $\begin{array}{c}\text { Sampling } \\
\text { site } \\
\text { number }\end{array}$ & $\mathrm{PI}_{\mathrm{Ni}}$ & PD & $\mathrm{PI}_{\mathrm{Cu}}$ & PD & $\mathrm{PI}_{\mathrm{As}}$ & PD & $\mathrm{PI}_{\mathrm{Pb}}$ & PD & $\mathrm{PI}_{\mathrm{Cd}}$ & PD & $\mathrm{PI}_{\mathrm{Zn}}$ & PD & NSWPI & PD & SDI \\
\hline \multicolumn{16}{|c|}{ May } \\
\hline 4 & $<0.1$ & \multirow{7}{*}{ NP } & 0.1 & \multirow{2}{*}{ NP } & $<0.1$ & \multirow{7}{*}{ NP } & $<0.1$ & \multirow{7}{*}{ NP } & $<0.1$ & \multirow{2}{*}{ NP } & $<0.1$ & \multirow{2}{*}{ NP } & $<0.1$ & \multirow{2}{*}{ NP } & 0.84 \\
\hline 5 & $<0.1$ & & 0.2 & & $<0.1$ & & 0.1 & & $<0.1$ & & 0.1 & & 0.2 & & 0.89 \\
\hline 6 & 0.1 & & 4.8 & HP & 0.1 & & 0.2 & & 1.3 & \multirow[b]{2}{*}{ PP } & 1.6 & \multirow{2}{*}{ PP } & 3.5 & HP & 0.64 \\
\hline 7 & $<0.1$ & & 1.6 & PP & 0.1 & & 0.1 & & 1.5 & & $>1.0$ & & 1.2 & SP & 0.77 \\
\hline 8 & 0.2 & & 15.8 & \multirow{2}{*}{ HP } & 0.1 & & 0.5 & & 7.8 & HP & 16.0 & \multirow{2}{*}{ HP } & 12.3 & \multirow{2}{*}{ HP } & 0.50 \\
\hline 9 & 0.2 & & 7.6 & & 0.1 & & 0.2 & & 2.2 & SP & 3.4 & & 5.6 & & 0.52 \\
\hline 10 & 0.2 & & 1.1 & $\mathrm{PP}$ & 0.1 & & 0.4 & & 0.7 & NP & 0.7 & NP & 0.8 & WLP & 0.78 \\
\hline \multicolumn{16}{|c|}{ August } \\
\hline 4 & $<0.1$ & \multirow{7}{*}{ NP } & 0.1 & ND & $<0.1$ & \multirow{7}{*}{ NP } & 0.1 & \multirow{7}{*}{ NP } & $<0.1$ & \multirow{2}{*}{ NP } & $<0.1$ & \multirow{2}{*}{ NP } & 0.1 & \multirow{2}{*}{ NP } & 0.89 \\
\hline 5 & $<0.1$ & & 0.2 & & $<0.1$ & & $<0.1$ & & $<0.1$ & & 0.1 & & 0.2 & & 0.86 \\
\hline 6 & 0.1 & & 6.3 & HP & 0.1 & & 0.2 & & 1.6 & DD & 2.7 & SP & 4.6 & HP & 0.69 \\
\hline 7 & 0.1 & & 1.7 & PP & 0.1 & & 0.1 & & 1.4 & & 1.2 & PP & 1.3 & SP & 0.78 \\
\hline 8 & 0.2 & & 7.6 & HP & $<0.1$ & & 0.6 & & 14.6 & HP & 26.0 & HP & 19.3 & HP & 0.48 \\
\hline 9 & 0.1 & & 1.7 & PP & $<0.1$ & & 0.2 & & 1.7 & PP & 2.1 & SP & 1.6 & SP & 0.66 \\
\hline 10 & $<0.1$ & & 0.4 & NP & 0.1 & & 0.1 & & 0.4 & NP & 0.2 & NP & 0.3 & NP & 0.83 \\
\hline
\end{tabular}

"PD" - pollution degree; "NP" - non-pollution; "WLP" - warning line of pollution; "PP" - potential pollution; "SP" - slight pollution; "HP" - heavy pollution 
Table 6. Results of the Pearson correlation analysis between individual heavy metal pollution degrees and between heavy metal pollution degree and phytoplankton species diversity according to the observation sites of the investigated rivers in the Lake Sevan catchment basin.

\begin{tabular}{|c|c|c|c|c|c|c|c|c|c|}
\hline & SDI & $\mathrm{PI}_{\mathrm{v}}$ & $P I_{\mathrm{Fe}}$ & $\mathrm{PI}_{\mathrm{Ni}}$ & $\mathrm{PI}_{\mathrm{Cu}}$ & $\mathrm{PI}_{\mathrm{As}}$ & $\mathrm{PI}_{\mathrm{Mo}}$ & $\mathrm{PI}_{\mathrm{Pb}}$ & NSWPI \\
\hline \multicolumn{10}{|c|}{ May } \\
\hline SDI & 1 & & & & & & & & \\
\hline $\mathrm{PI}_{\mathrm{v}}$ & -0.984 & 1 & & & & & & & \\
\hline $\mathrm{PI}_{\mathrm{Fe}}$ & -0.653 & 0.509 & 1 & & & & & & \\
\hline $\mathrm{PI}_{\mathrm{Ni}}$ & 0.902 & -0.811 & -0.916 & 1 & & & & & \\
\hline $\mathrm{PI}_{\mathrm{Cu}}$ & -0.912 & 0.825 & 0.906 & -0.999 & 1 & & & & \\
\hline $\mathrm{PI}_{\mathrm{As}}$ & -0.997 & 0.995 & 0.591 & -0.865 & 0.877 & 1 & & & \\
\hline $\mathrm{PI}_{\mathrm{Mo}}$ & -0.897 & 0.961 & 0.251 & -0.618 & 0.637 & 0.929 & 1 & & \\
\hline $\mathrm{PI}_{\mathrm{Pb}}$ & -0.966 & 0.997 & 0.435 & -0.759 & 0.775 & 0.983 & 0.981 & 1 & \\
\hline NSWPI & -0.962 & 0.995 & 0.421 & -0.749 & 0.765 & 0.980 & 0.984 & 0.999 & 1 \\
\hline \multicolumn{10}{|c|}{ August } \\
\hline SDI & 1 & & & & & & & & \\
\hline $\mathrm{PI}_{\mathrm{v}}$ & -0.956 & 1 & & & & & & & \\
\hline $\mathrm{PI}_{\mathrm{Fe}}$ & -0.937 & 0.792 & 1 & & & & & & \\
\hline $\mathrm{PI}_{\mathrm{Ni}}$ & 0.975 & -0.865 & -0.991 & 1 & & & & & \\
\hline $\mathrm{PI}_{\mathrm{Cu}}$ & -0.958 & 0.832 & 0.998 & -0.998 & 1 & & & & \\
\hline $\mathrm{PI}_{\mathrm{As}}$ & -0.343 & 0.051 & 0.650 & -0.545 & 0.596 & 1 & & & \\
\hline $\mathrm{PI}_{\mathrm{Mo}}$ & -0.735 & 0.503 & 0.926 & -0.868 & 0.898 & 0.889 & 1 & & \\
\hline $\mathrm{PI}_{\mathrm{Pb}}$ & -0.840 & 0.963 & 0.597 & -0.697 & 0.651 & -0.221 & 0.250 & 1 & \\
\hline NSWPI & -0.919 & 0.994 & 0.723 & -0.808 & 0.769 & -0.055 & 0.409 & 0.986 & 1 \\
\hline
\end{tabular}

by anthropogenic influence (Tables 2 and 3). Although river observation site Nos. 1 and 4 flowed through areas that were not exposed to significant heavy metal pollution, the other sampling sites of the investigated rivers (except No. 5) were affected by mining and metallurgical industrial activities in the Sevan and Debed basins.

In the Sevan basin, heavy metal pollution degree from upstream of the Sotq River to the mouth of the Masrik River (sampling site Nos. 1-3) increased, which may have been conditioned by the influence of gold mining activity (Sotq gold mine) as the Masrik and its tributary passing through the gold mining area were exposed to heavy metal pollution (Table 4).

In the Debed basin the significant heavy metal pollution of the river ecosystems registered especially in sampling site Nos. 6-9, where the pollution degree may have posed health risks to aquatic life (Table 5). The main factors that may have affected heavy metal content in these observation sites are:

- The Alaverdi River site located near the river mouth (No. 6) may have been influenced by Alaverdi copper smelter (including the tailing dump) activity.

- The Debed River site is located about $4.5 \mathrm{~km}$ downstream from Alaverdi town (No. 7), and by
Alaverdi copper smelter (including tailing dump) activity and the pressure of its tributary, the Alaverdi river.

- The Akhtala River site is located near the river mouth (No. 8) by the Akhtala mountain enrichment combine (including tailing dump) activity.

- The Chochkan River site is located downstream from Chochkan tailing dump (No. 9) - by the Chochkan tailing dump activity.

The degree of heavy metal pollution in the Debed River site near Ayrum town was lower than that in the Debed site about $4.5 \mathrm{~km}$ downstream from Alaverdi, which is explained by the distance from the pollution sources as large quantities of heavy metals moving along the river not only settle to the bottom but also accumulate in aquatic organisms.

The investigated heavy metals can be ranked by anthropogenic pollution degree for river ecosystem health as follows: $\mathrm{Ni}>\mathrm{Fe}>\mathrm{V}>\mathrm{Mo}>\mathrm{As}>\mathrm{Cu}>\mathrm{Pb}$ in sampling site No. 1, $\mathrm{V}>\mathrm{Fe}>\mathrm{Mo}>\mathrm{Ni}>\mathrm{As}>\mathrm{Cu}>\mathrm{Pb}$ in sampling site No. 2, $\mathrm{V}>\mathrm{Fe}>\mathrm{Mo}>\mathrm{As}>\mathrm{Ni}>\mathrm{Pb}>\mathrm{Cu}$ in sampling site No. 3, $\mathrm{Cu}>\mathrm{Pb}>\mathrm{Zn}>\mathrm{Ni}>\mathrm{As}>\mathrm{Cd}$ in sampling site No. 4, $\mathrm{Cu}>\mathrm{Zn}>\mathrm{Pb}>\mathrm{Ni}>\mathrm{As}>\mathrm{Cd}$ in sampling site No. 5, $\mathrm{Cu}>\mathrm{Zn}>\mathrm{Cd}>\mathrm{Pb}>\mathrm{Ni}>\mathrm{As}$ in sampling sites Nos. 6 
Table 7. Results of the Pearson correlation analysis between individual heavy metal pollution degrees and between heavy metal pollution degree and phytoplankton species diversity according to the observation sites of the investigated rivers in the Debed river catchment basin.

\begin{tabular}{|c|c|c|c|c|c|c|c|c|}
\hline & SDI & $\mathrm{PI}_{\mathrm{Ni}}$ & $\mathrm{PI}_{\mathrm{Cu}}$ & $\mathrm{PI}_{\mathrm{As}}$ & $\mathrm{PI}_{\mathrm{Pb}}$ & $\mathrm{PI}_{\mathrm{Cd}}$ & $\mathrm{PI}_{\mathrm{Zn}}$ & NSWPI \\
\hline \multicolumn{9}{|c|}{ May } \\
\hline SDI & 1 & & & & & & & \\
\hline $\mathrm{PI}_{\mathrm{Ni}}$ & -0.842 & 1 & & & & & & \\
\hline $\mathrm{PI}_{\mathrm{Cu}}$ & -0.895 & 0.714 & 1 & & & & & \\
\hline $\mathrm{PI}_{\mathrm{As}}$ & -0.831 & 0.701 & 0.903 & 1 & & & & \\
\hline $\mathrm{PI}_{\mathrm{Pb}}$ & -0.668 & 0.772 & 0.727 & 0.796 & 1 & & & \\
\hline $\mathrm{PI}_{\mathrm{Cd}}$ & -0.777 & 0.597 & 0.963 & 0.934 & 0.734 & 1 & & \\
\hline $\mathrm{PI}_{\mathrm{Zn}}$ & -0.736 & 0.577 & 0.956 & 0.885 & 0.728 & 0.991 & 1 & \\
\hline NSWPI & -0.887 & 0.707 & 0.999 & 0.906 & 0.731 & 0.968 & 0.962 & 1 \\
\hline \multicolumn{9}{|c|}{ August } \\
\hline SDI & 1 & & & & & & & \\
\hline $\mathrm{PI}_{\mathrm{Ni}}$ & -0.976 & 1 & & & & & & \\
\hline $\mathrm{PI}_{\mathrm{Cu}}$ & -0.870 & 0.748 & 1 & & & & & \\
\hline $\mathrm{PI}_{\mathrm{As}}$ & -0.453 & 0.372 & 0.535 & 1 & & & & \\
\hline $\mathrm{PI}_{\mathrm{Pb}}$ & -0.926 & 0.878 & 0.842 & 0.266 & 1 & & & \\
\hline $\mathrm{PI}_{\mathrm{Cd}}$ & -0.875 & 0.831 & 0.782 & 0.170 & 0.990 & 1 & & \\
\hline $\mathrm{PI}_{\mathrm{Zn}}$ & -0.862 & 0.813 & 0.782 & 0.139 & 0.987 & 0.999 & 1 & \\
\hline NSWPI & -0.886 & 0.816 & 0.855 & 0.219 & 0.990 & 0.989 & 0.992 & 1 \\
\hline
\end{tabular}

and 9, $\mathrm{Cu}>\mathrm{Cd}>\mathrm{Zn}>\mathrm{Pb}>\mathrm{As}>\mathrm{Ni}$ in sampling site No. 7, $\mathrm{Zn}>\mathrm{Cu}>\mathrm{Cd}>\mathrm{Pb}>\mathrm{Ni}>\mathrm{As}$ in sampling site No. 8, and $\mathrm{Cu}>\mathrm{Cd}>\mathrm{Zn}>\mathrm{Pb}>\mathrm{Ni}>\mathrm{As}$ in sampling site No. 10 (Tables 4 and 5).

From the point of view of heavy metal pollution induced by gold mining activity in the Sevan basin, $\mathrm{V}$ was the only limiting factor for aquatic life (Table 4). The high level of $\mathrm{V}$ in water systems may negatively affect aquatic life, causing the inhibition of certain enzymes, which have several neurological effects. Besides the neurological effects, V can cause breathing disorders, paralysis, and negative effects on the liver and kidneys [46-47]. An increase in $\mathrm{V}$ consumption in humans can cause anemia, inflammation, swelling around the eyes, inflammation of the lungs, cataracts, cognitive deficits, diarrhea, and a decrease in appetite [46]. In the Debed basin, $\mathrm{Cu}, \mathrm{Cd}$, and $\mathrm{Zn}$ contents were formed due to mining activities, which may have limited the growth of aquatic organisms (Table 5). Elevated levels of these metals in an aquatic ecosystem may cause liver and kidney damage, neurological effects, etc. An increase in $\mathrm{Cu}, \mathrm{Cd}$, and $\mathrm{Zn}$ consumption in humans can lead to serious diseases and ailments such as Wilson disease, insomnia, lethargy, renal disorder, cancer, increased thirst, etc. [7].

For verifying the possible impact of the heavy metal pollution of the rivers on aquatic life, we investigated the phytoplankton communities in the Sevan and Debed basin ecosystems. Simultaneous increases in primary production and phytoplankton species diversity indicates ecological progress in case of which Simpson diversity index (SDI) has a high value (close to 1). According to the observation sites of the investigated rivers in the Lake Sevan and Debed river catchment basins, decreased SDI values were especially registered in observation site Nos. 2, 3, 6-10 (Tables 4 and 5). Correlation analysis revealed not only a high positive correlation between pollution degrees of almost all the investigated heavy metals, but also a high negative correlation between heavy metal pollution degree and phytoplankton species diversity (SDI) according to the river observation sites in the Sevan and Debed basins (Tables 6 and 7). All of this indicated that almost all the heavy metals in each investigated site had the same anthropogenic sources, and the changes in the species diversity of planktonic algae were mainly conditioned by the impact of heavy metal pollution induced by mining and metallurgical industrial activities in the two basins.

Heavy metals are non-degradable substances, and the heavy metal pollution of freshwater systems may pose health risks not only for aquatic ecosystems but also humans. It can increase health risks through the water-food chain and different exposure pathways such as oral ingestion and dermal contact [48]. Potential health hazards in the case of river water use for drinking and domestic (bathing/showering) purposes also were 
a)

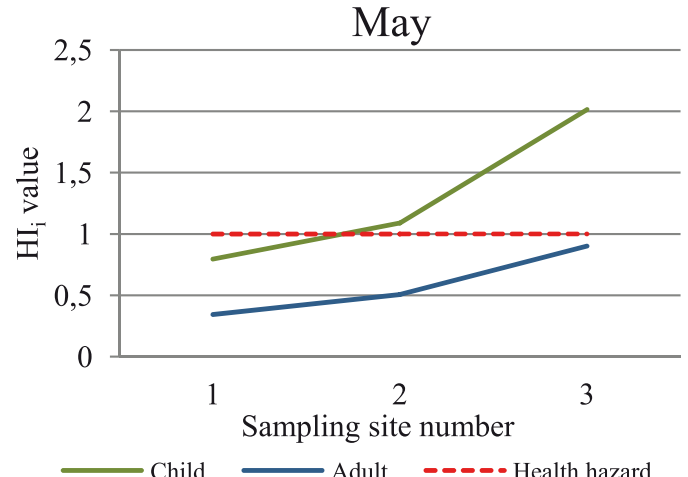

c)

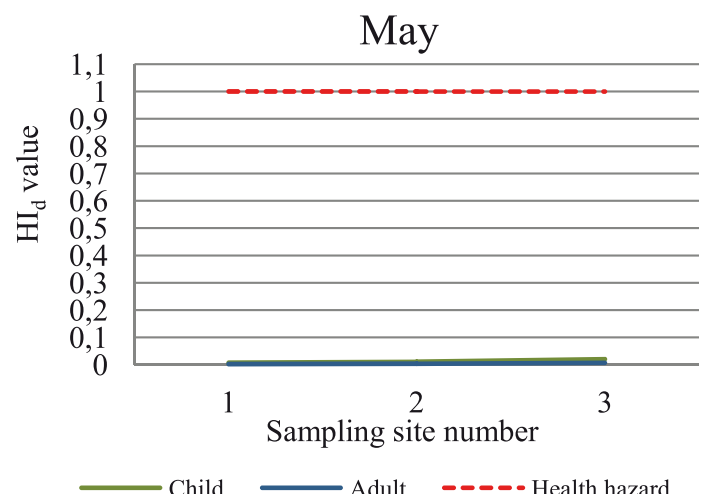

b)

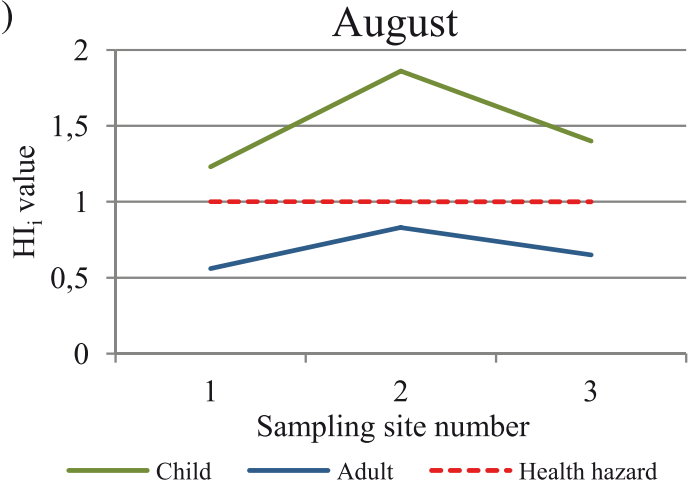

d)

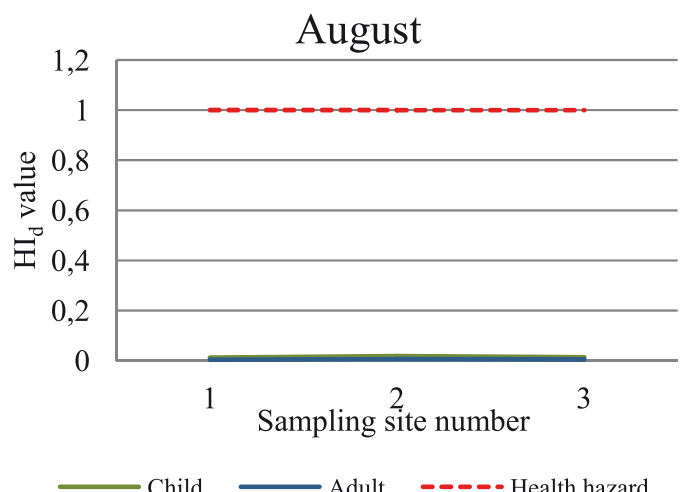

Fig. 4. Values of the non-carcinogenic chronic hazard index (HI) of heavy metals in the waters of the investigated rivers in the Lake Sevan catchment basin.

a)

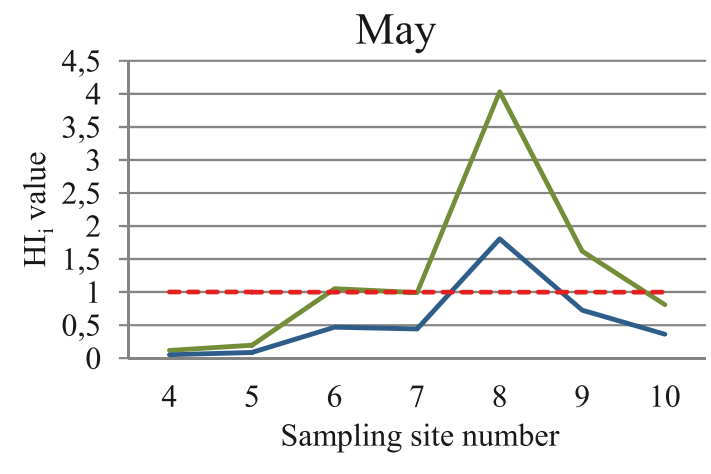

c)

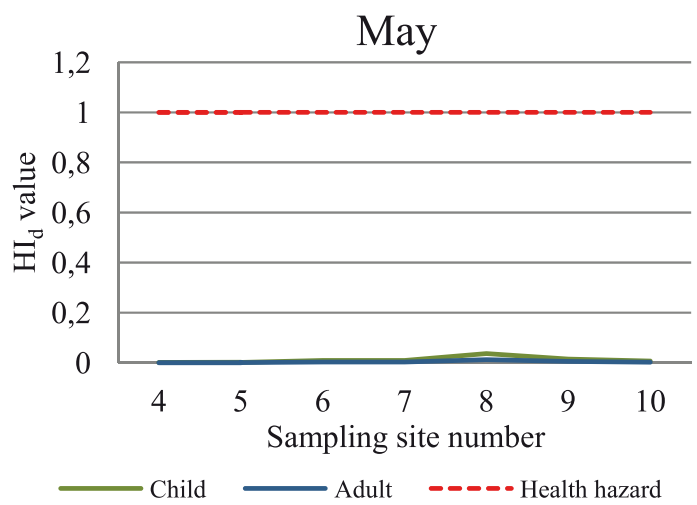

b)

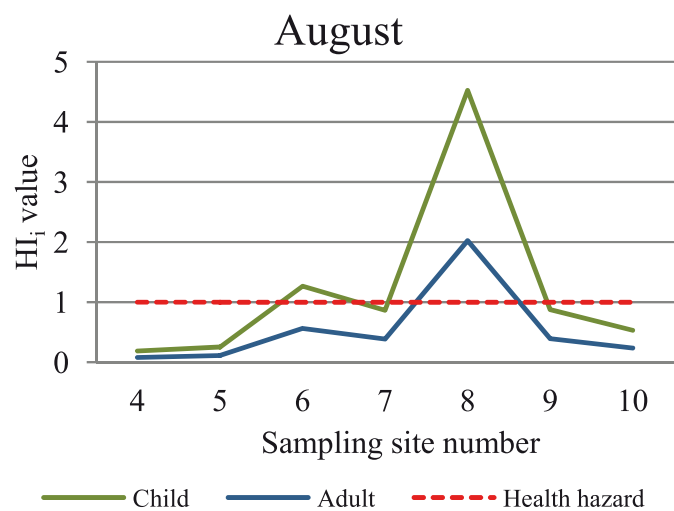

d)

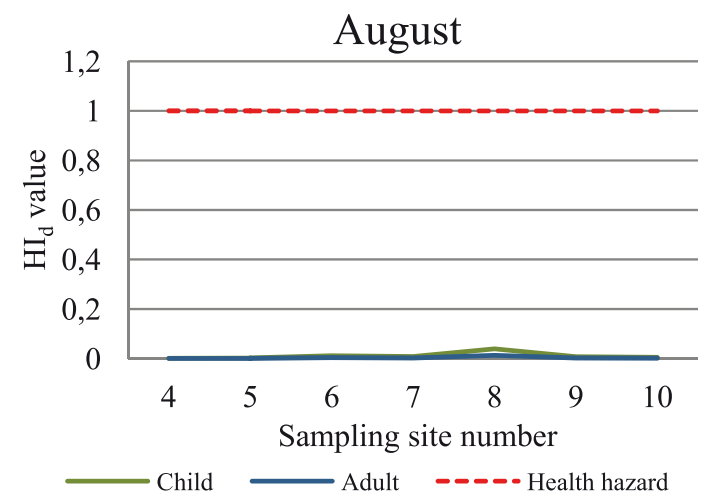

Fig. 5. Values of the non-carcinogenic chronic hazard index (HI) of heavy metals in the waters of the investigated rivers in the Debed river catchment basin. 
assessed. Investigations showed that in the case of water used for drinking purposes, health risks to children may have been posed from all the investigated river sites in the Sevan basin and river observation site Nos. 6, 8, and 9 in the Debed basin, and health risks to adults may have been posed only from observation site No. 8 (Figs. 4a,b and $5 a, b)$. According to heavy metal concentrations, the waters in the observation sites of the investigated rivers in the Sevan and Debed basins may have been used for bathing/ showering purposes without undertaking precautionary measures (4c,d and 5c,d).

According to the individual metal non-carcinogenic hazard index $\left(\mathrm{HI}_{\mathrm{m}}\right)$ values, the health hazards of individual heavy metals falls in the following order: $\mathrm{As}>\mathrm{Ni}>\mathrm{V}>\mathrm{Fe}>\mathrm{Mo}>\mathrm{Pb}>\mathrm{Cu}$ in sampling site No. 1, $\mathrm{As}>\mathrm{V}>\mathrm{Ni}>\mathrm{Fe}>\mathrm{Mo}>\mathrm{Pb}>\mathrm{Cu}$ in sampling site No. 2, $\mathrm{As}>\mathrm{V}>\mathrm{Fe}>\mathrm{Pb}>\mathrm{Mo}>\mathrm{Ni}>\mathrm{Cu}$ in sampling site No. 3, $\mathrm{As}>\mathrm{Pb}>\mathrm{Cu}>\mathrm{Ni}>\mathrm{Cd}>\mathrm{Zn}$ in sampling site Nos. 4 and 5, $\mathrm{As}>\mathrm{Cu}>\mathrm{Cd}>\mathrm{Pb}>\mathrm{Zn}>\mathrm{Ni}$ in sampling site No. 6, $\mathrm{As}>\mathrm{Cd}>\mathrm{Cu}>\mathrm{Zn}>\mathrm{Pb}>\mathrm{Ni}$ in sampling site Nos. 7 and 9, $\mathrm{Cd}>\mathrm{As}>\mathrm{Cu}>\mathrm{Zn}>\mathrm{Pb}>\mathrm{Ni}$ in sampling site No. 8, and $\mathrm{As}>\mathrm{Cd}>\mathrm{Pb}>\mathrm{Cu}>\mathrm{Zn}>\mathrm{Ni}$ in sampling site No. 10. Although As pollution degree for the ecosystem health of the investigated rivers in the Sevan and Debed basins was lower than the pollution degree of most of the investigated heavy metals, the highest and most significant health hazards in the case of drinking water may have been posed by this metal (Tables 4 and 5). This is explained by the toxicity levels and penetration characteristics of individual heavy metals, as some metals that have high toxicity and penetration capacity may cause health effects even at low concentrations, but others having lower toxicity and penetration capacity may pose health risks at higher degrees of pollution [49]. All of this indicates that the determination of individual heavy metal pollution degrees in water isn't sufficient to precisely assess related human health hazards as in this case, where the toxicity level and penetration capacity of metal are also important and should be taken into consideration.

\section{Conclusions and Path Forward}

In general, it is possible to state that mining and metallurgical industrial activities in the Lake Sevan and Debed River catchment basins caused significant heavy metal (especially $\mathrm{V}$ in the Sevan basin and $\mathrm{Cu}, \mathrm{Cd}$, and $\mathrm{Zn}$ in the Debed basin) pollution of the Sotq, Masrik (Lake Sevan catchment basin), Debed, Alaverdi, Akhtala, and Chochkan (Debed river catchment basin) rivers, which may have posed health risks to aquatic organisms. The investigation of phytoplankton community in the rivers revealed a high negative correlation between species diversity of planktonic algae and heavy metal pollution degree, which indicated that a decrease in phytoplankton diversity was mainly conditioned by the influence of heavy metal pollution induced by mining and metallurgical industrial activities in the Sevan and Debed basins. Heavy metal (V, Fe, Ni, Cu, As, Mo, $\mathrm{Pb}, \mathrm{Cd}, \mathrm{Zn}$ ) pollution degree in the rivers investigated may also have posed health risks to humans, especially in the case of river water used for drinking purposes. To mitigate such health risks, policy makers need to implement strict regulations on mining and industry on containment and discharge of waste and byproducts.

\section{Acknowledgements}

The authors express their gratitude for funding from NATO, an SfP 984403 grant that provided support for this investigation.

\section{References}

1. KAWAHATA H., YAMASHITA S.H., YAMAOKA K., OKAI T., SHIMODA G., IMAI N. Heavy metal pollution in Ancient Nara, Japan, during the eighth century, Progress in Earth and Planetary Science, 1 (15), 1, 2014.

2. AFRIFA C.G., OFOSU F.G., BAMFORD S.A., WORDSON D.A., ATIEMO S.M., ABOH I.J.K., ADETI J.P. Heavy metal contamination in surface soil dust at selected fuel filling stations in Accra, Ghana, American Journal of Scientific and Industrial Research, 4 (4), 404, 2013.

3. GHAZARYAN K.A., MOVSESYAN H.S., GHAZARYAN N.P., GEVORGYAN G.A., GRIGORYAN K.V. General characteristic of soils of Kajaran town surroundings, Proceedings of the Yerevan State University, 232 (3), 44, 2013.

4. BICHI M.H., BELLO U.F. Heavy metal pollution in surface and ground waters used for irrigation along River Tatsawarki in the Kano, Nigeria, IOSR Journal of Engineering, 3 (8), $1,2013$.

5. DONG D., LIU X., GUO ZH., HUA X., SU Y., LIANG D. Seasonal and spatial variations of heavy metal pollution in water and sediments of China's Tiaozi River, Polish Journal of Environmental Studies, 24 (6), 2371, 2015.

6. NASER H.A. Assessment and management of heavy metal pollution in the marine environment of the Arabian Gulf: A review, Marine Pollution Bulletin, 72 (1), 6, 2013.

7. PARMAR M., THAKUR L.S. Heavy metal $\mathrm{Cu}, \mathrm{Ni}$ and $\mathrm{Zn}$ : Toxicity, health hazards and their removal techniques by low cost adsorbents: A short review, International Journal of Plant, Animal and Environmental Sciences, 3 (3), 143, 2013.

8. ZAMANI A.A., YAFTIAN M.R., PARIZANGANEH A. Multivariate statistical assessment of heavy metal pollution sources of groundwater around a zinc and lead plant, Iranian Journal of Environmental Health Sciences and Engineering, 9 (29), 1, 2012.

9. ZHANG CH., QIAO Q., PIPER J.D.A., HUANG B. Assessment of heavy metal pollution from a Fe-smelting plant in urban river sediments using environmental magnetic and geochemical methods, Environmental Pollution, 159 (10), 3057, 2011.

10. AL OBAIDY A.H.M.J., AL MASHHADY A.A.M., AWAD E.S., KADHEM A.J. Heavy metal pollution in surface water of Mahrut River, Diyala, Iraq, International Journal of Advanced Research, 2 (10), 1039, 2014.

11. DIVYA K.S., MAHADEVA M.S., Study of water quality assessment using water quality index (WQI) in few water samples of Karnataka and Kerala states, International Journal of Recent Scientific Research, 4 (3), 267, 2013. 
12. MISGANAW T.S. Physico-chemical studies on the pollution level of Stream Bisnit, Gondar, Ethiopia, Journal of Environment and Earth Science, 5 (21), 64, 2015.

13. MOGHADDAM M.H., LASHKARIPOUR G.H.R., DEHGHAN P. Assessing the effect of heavy metal concentrations ( $\mathrm{Fe}, \mathrm{Pb}, \mathrm{Zn}, \mathrm{Ni}, \mathrm{Cd}, \mathrm{As}, \mathrm{Cu}, \mathrm{Cr})$ on the quality of adjacent groundwater resources of Khorasan Steel Complex, International Journal of Plant, Animal and Environmental Sciences, 4 (2), 511, 2014.

14. MOHOD CH.V., DHOTE J. Review of heavy metals in drinking water and their effect on human health, International Journal of Innovative Research in Science, Engineering and Technology, 2 (7), 2992, 2013.

15. MUSTAPHA O.M., LAWAL O.S. Comparative study of heavy metal pollution of sediments in Odo-Owa and Yemoji Streams, Ijebu-Ode local government area, SW Nigeria, IOSR Journal of Applied Chemistry, 7 (12), 17, 2014.

16. OLGUNOGLU M.P., OLGUNOGLU I.A., BAYHAN Y.K. Heavy metal concentrations $(\mathrm{Cd}, \mathrm{Pb}, \mathrm{Cu}, \mathrm{Zn}, \mathrm{Fe})$ in Giant Red Shrimp (Aristaeomorpha foliacea Risso 1827) from the Mediterranean Sea, Polish Journal of Environmental Studies, 24 (2), 631, 2015.

17. VASEASHTA A. Life cycle of nanomaterials - Risk, Assessment, and Sustainability, Destech Publications, Chester, PA, 2015.

18. ZHOU Q., ZHANG J., FU J., SHI J., JIANG G. Biomonitoring: An appealing tool for assessment of metal pollution in the aquatic ecosystem, Analytica Chimica Acta, $606(2), 135,2008$.

19. LIU R., LIU J., ZHANG Z.H., BORTHWICK A., ZHANG $\mathrm{K}$. Accidental water pollution risk analysis of mine tailings ponds in Guanting reservoir watershed, Zhangjiakou city, China, International Journal of Environmental Research and Public Health, 12 (12), 15269, 2015.

20. GOSAR M. Environmental impacts of metal mining, RMZ Materials and Geoenvironment, 51 (4), 2097, 2004.

21. BOOK F. Risk assessment of mining effluents in surface water downstream the sulphide ore mine Aitik, northern Sweden. Master thesis, University of Gothenburg, 2014.

22. GEVORGYAN G.A., HAMBARYAN L.R., GRIGORYAN K.V., MINASYAN S.H. Heavy metal pollution of the catchment basins of the Voghchi and Meghriget rivers (Armenia) and risks to the environment associated with water pollution, Academic Journal of Science, 2 (2), 255, 2013

23. MONDAL K., SAYAN J. A review of the effects of heavy metals on the aquatic animal of three different districts of West Bengal, Journal of Global Biosciences, 4 (6), 2504, 2015.

24. NIYOGI D.K., LEWIS JR. W.M., MCKNIGHT D.M. Effects of stress from mine drainage on diversity, biomass, and function of primary producers in mountain streams, Ecosystems, 5 (6), 554, 2002.

25. TAKARINA N.D., ADIWIBOWO A. Impact of heavy metals contamination on the biodiversity of marine benthic organisms in Jakarta bay, Journal of Coastal Development, 14 (2), 168, 2011.

26. TUOVINEN N., WECKSTROM K., SALONEN V. Impact of mine drainage on diatom communities of Orijarvi and Maajarvi lakes in SW Finland, Boreal Environment Research, 17 (6), 437, 2012.

27. GABRIELYAN B.K. Fish of Lake Sevan. Yerevan, "Gitutyun", 2010 [In Russian].

28. HOVHANNISSIAN R.H. Lake Sevan yesterday, today... Yerevan, "Gitutyun", 1994 [In Russian, with extended summaries in English and Armenian].
29. MANASYAN M.G., GRIGORYAN A.T., EGHYAN G.B. Lori marz - nature, population, economy. Yerevan, "EPH", 2003 [In Armenian].

30. CHILINGARYAN L.A., MNACAKANYAN B.P. Hydrology of Lake Sevan: Hydrology of Lake Sevan catchment basin. In book: Ecology of Lake Sevan during the period of water level rise (The results of Russian-Armenian biological expedition for hydroecological survey of Lake Sevan (Armenia) (2005-2009)). Makhachkala, "Nauka DNC", 14, 2010 [In Russian].

31. CHILINGARYAN L.A., MNACAKANYAN B.P. Hydrology of Lake Sevan: Physical and geographic characteristics and climatic conditions of catchment basin. In book: Ecology of Lake Sevan during the period of water level rise (The results of Russian-Armenian biological expedition for hydroecological survey of Lake Sevan (Armenia) (2005-2009)). Makhachkala, "Nauka DNC", 7, 2010 [In Russian].

32. DANIELYAN A.A. Ecological assessment of the Debed river and its catchment basin and the perspectives for the sustainable development of the area. PhD thesis, Yerevan, 2009 [In Armenian].

33. ABAKUMOV V. (edtd.), Guide on the hydrobiological monitoring of freshwater ecosystems. St. Petersburg, "Gidrometeoizdat", 1992 [In Russian].

34. PROSHKINA-LAVRENKO A.I., MAKAROVA I.V. Plankton algae of the Caspian Sea. Leningrad, "Nauka", 1968 [In Russian].

35. TSARENKO P.M. Short guidebook of the chlorococcal algae of the Ukrainian SSR. Kiev, "Naukova dumka", 1990 [In Russian].

36. ZABELINA M.M., KISELEV I.A., PROSHKINALAVRENKO A.I., SHESHUKOVA V.S. Determinant of the freshwater algae of the USSR. Diatom algae. Issue 4, Moscow, "Sovetskaya nauka", 1951 [In Russian].

37. American society for testing and materials. Standard methods for acidity or alkalinity of water. Publ. D1067-70 (reapproved 1977), American Soc. Testing and Materials Philadelphia, PA, 1982.

38. SINGH P.K., VERMA P., TIWARI A.K., SHARMA SH., PURTY P. Review of various contamination index approaches to evaluate groundwater quality with geographic information system (GIS), International Journal of Chem. Tech Research, 7 (4), 1920, 2014-15.

39. Ecological norms recommended for the surface waters of the Republic of Armenia (RA Government Resolution №75-N as of January 27, 2011) (in Armenian). Available at: http://www.armmonitoring.am/Documentations/MAR75\%5B1\%5D.1.pdf

40. NEMEROW N.L., SUMITOMO H. Benefit of water quality enhancement. Report № 16110 DAJ, U.S. Environmental Protection Agency. Syracuse University, Syracuse, New York, 1970.

41. U.S. Environmental Protection Agency (US EPA): Risk Assessment guidance for superfund. Vol. I: Human health evaluation manual (Part A). US EPA, Washington, DC, USA, (EPA/540/1-89/002), 1989.

42. Human health risk assessment (Appendix A). Available at: http://www.tva.gov/kingston/eeca/App\%20A\%20HHRA. pdf

43. U.S. Environmental Protection Agency (US EPA). Integrated risk information system. Available at: http://cfpub.epa.gov/ ncea/iris/compare.cfm.

44. World Health Organization (WHO). Evaluation of certain food additives and contaminants. In: Forty-first report of the Joint FAO/WHO Expert Committee on Food Additives. 
WHO, Geneva, Switzerland, (WHO Technical Series, 837), 1993.

45. SIMPSON E.H. Measurement of diversity, Nature, 163, 688, 1949.

46. MOGHDANI S., PAZIRA A.R., GHANBARI F., ZADEH N.J. Vanadium concentration levels in muscle tissues of two commercial fish species in Persian Gulf waters, AACL Bioflux, 7 (6), 498, 2014.

47. ZAKI M.S., SHARAF N.E., OSFOR M.H. Effect of vanadium toxicity in Clarias lazera, Journal of American Science, 6 (12), 1, 2010.
48. MALASSA H., AL-QUTOB M., AL-KHATIB M., ALRIMAWI F. Determination of different trace heavy metals in ground water of South West Bank/Palestine by ICP/MS, Journal of Environmental Protection, 4 (8), 818, 2013.

49. GEVORGYAN G.A., MOVSESYAN H.S., GRIGORYAN K.V., GHAZARYAN K.A. Environmental risks of heavy metal pollution of the soils around Kajaran town, Proceedings of the Yerevan State University, 237 (2), 50, 2015. 